UDC $621.318 .38: 621,335.9: 625.39: 625.14$

\title{
シート軌道超電導磁気浮上系の磁気ダン ピング係数とばね係数
}

\begin{tabular}{|l|}
\hline 論 文 \\
\hline $54-B$ 9 96 \\
\hline
\end{tabular}

\author{
正員吉田 欣二郎 九 九) \\ 准員高倉正実(九大)
}

\section{1.まえがき}

時速 $500 \mathrm{~km}$ 超高速鉄道の磁気浮上方式は, 超電導 コイルを用いる誘導反発方式が最も理想的なむのとし て世界各国で盛九に研究開発されている。この磁気浮 上方式は，車上に塔載の超電導電磁石之地上に䋯設の 導電性金属板（主にアルミニウム板），あるいは短絡 コイルとの間化働く電磁反発力を列車の浮上力として 利用するものである。前者はシート軌道方式，後者は ループ軌道方式と呼ばれる。

超電導磁気浮上式鉄道の実猊には，車両の上下振動 に対する動的安定性と乘り心地が重要な問題の一つで ある。とれは微小振動汇関する磁気ダンピング係数と ば初係数を用いて評洒でき，両係数の解明が望まれ る。ループ軌道方式の磁気ダンピング保数は, 定電流 モードに括いて，車上コイルの交番極性配列の場合中

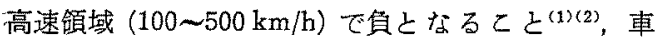
上コイルの同極性配列の場合中高速領域でも正となる こと ${ }^{(3)}$ が理論的に明らかにされている。しかしなが ら,シート軌道方式の磁気ダンピング係数とばね係数 代関しては，永久電流モードの場合はすちろん定電流 モードの場合もまだほとんど解明されていない。最 近，B.T. Ooi 氏は永久電流モードにおりる解析を発 表した(4)が，シートの有限幅効果が考慮されている反 面車上コイルの有限個配列による列車端端部効果が無 視されており，しかす永久電流モードにおりる取报い が不完全であるなど末解明な点が多い。

本論文は，永久電流モードにおける磁気ダンピング 係数とば称係数が，車両の上下振動に直接起因するシ 一ト軌道のうず電流現象と上下振動による車上コイル 電流の変化を介して複雑に関与する異質のうず電流現 象とに依存することを明確にし，端部効果を考慮に入

Magnetic Damping and Stiffness Coefficients in Superconducting Maglev System with Sheet Guideways, By Kinjiro Yoshida, Member \& Masami Takakura, Associate (Faculty of Engineering, Kyushu University).

吉田欣二郎: 正貴，九州大学工学部電気工学科

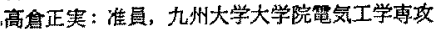

昭 $54-12$
れるために独自の空間高調波解析䘮行ない，少なく之 あ定電流モードでは正の磁気ダンピングとなることを 解析的㳊明ら加しし，乙加定電流モードと永久電流 モードに括ける磁気ダンピング係数とばる係数は，交 番極性配列の場合常正であるか，その值汇扔いて本 質的に大きく異なることを理諭的に明らかにしたもの である(5)。

\section{2. 線形撖動法}

本章では，シート軌道の上方 $h$ を一定速度 $v_{2}$ で $x$ 方向汇走行する列車偘載の超電導コイル群が上下方 向 ( $z$ の正負方向) に微小な振動をする場合の磁気ダ ンピング係数とば称係数の導出方法について述べる。

車両に㗢く電磁浮上力を $F_{L}$ ，車両の質量を $M$ 上す ると空気によるダンピング力在無視する場合車両の z

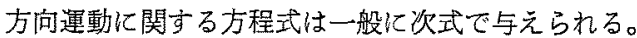

$$
M \ddot{z}_{0}=F_{L}\left(z_{0}, \dot{z}_{0}\right)-M g
$$

但し， $z_{0}$ は車上コイルの中心と轨道下側表面との 間の距離, $\dot{z}_{0}$ 之 $\ddot{z}_{0}$ 岵車上コイルの $z$ 方向速度之加速 度またgは重力の加速度である。

車上コイルの運動は, シート軌道の厚さをdとして 次のように仮定する。

$$
\begin{aligned}
& z_{0}(t)=z_{0}{ }^{\prime}(t)+z_{1}(t) . \\
& z_{0}{ }^{\prime}(t)=h+d+v_{z} t . \\
& \dot{z}_{0}(t)=v_{z}+\dot{z}_{1}(t) \ldots .
\end{aligned}
$$

上式で $z_{1}(t)$ 己 $\dot{z}_{1}(t)$ は定常状態 $\left(z 0^{\prime}, v_{z}\right)$ 加らの微 小な変化量を示す。つまり, 車上コイル群は高さ $h$ 加 ら出発して $z$ 方向に一定速度 $v_{z}$ で動く定常状龍加ら， $z_{1}(t)$ だけ微小変位し同時に $\dot{z}_{1}(t)$ だけ速度が微小変化 するものと考える。速度 $v_{x}$ は解析の便宜上導入する むので，解析後はすべて $v_{z}=0$ とおく。

車上コイル群の上下振動時の磁気ダンピング力は速 度 $\dot{z} 0(t)$ によって誘導されるシート轨道のうず電流損 任起因する。シートのうず電流解析注，車上コイル群 の上下方向運動を考える代わりに，乙れと等価なシー 卜靲道の㞄動に着目し，第1図に示すようにシート軌 


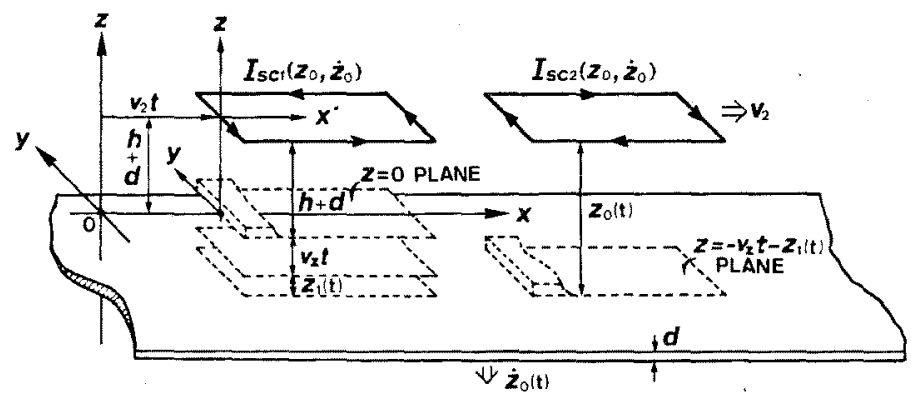

第 1 図 車上コイルの微小振動 応答解析に用いたシート軌道磁気 浮上系の構成図

Fig. 1. Configuration of Maglev system with sheet guideway used to analyze the small perturbation response of the vehicle coils.
道の方が 2 方向に一 $\dot{z}_{0}(t)$ で移動すると考えれば容㚙 である。第 1 图にあいて， $x, y, z$ 座標は空間に固定 された座標系を構成し， $t=0$ の瞬䦔シート軌道の下側 表面は $z=0$ 平面に一致孛る。永久電流モードの場合 のように，定常状態です車上コイル電流が列車速度

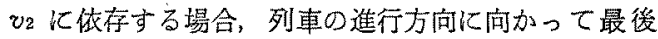
のコイルから第 $i$ 番目の車上コイル電流を図のように $I_{s c i}\left(z_{0}, \dot{z} 0\right)$ 乙すれば，(1) 式の浮上力は $P_{s c}$ 個の全 車上コイル電流走眿に含んだ开で次式で与えられる。

$$
F_{L}\left(z_{0}, \dot{z}_{0}\right)=F_{L}\left[z_{0}, \dot{z}_{0}, I_{s c 1}\left(z_{0}, \dot{z}_{0}\right)\right. \text {, }
$$$$
\left.\cdots, I_{s c p}\left(z_{0}, \dot{z}_{0}\right)\right]
$$

但し，

$$
\begin{array}{r}
I_{s c i}\left(z_{0}, \dot{z}_{0}\right)=I_{s c i}\left(z_{0}{ }^{\prime}, v_{z}\right)+\Delta I_{s c i}\left(z_{0}, \dot{z}_{0}\right) \\
\left(i=1,2, \cdots, P_{s c}\right) \ldots \ldots \ldots \ldots \ldots \ldots \ldots
\end{array}
$$

(6)式の $\Delta I_{s c i}\left(z_{0}, z_{0}\right)$ は定常電流 $I_{s e i}\left(z_{0^{\prime}}, v_{x}\right)$ 加 の微小な変化賱を示す。

(1) 式に(2) （6)式古代入して，一定の浮上高さ $h$ で浮上力之車耐算量がつり合っている浮上走行の平 衡点 $\left(z z^{\prime}=h+d, v_{x}=0, I_{s c 1}, \cdots, I_{s c p}\right)$ の周りで線形 化すると，次の䵊分方程式を得る。

$$
\begin{aligned}
& M \ddot{z}_{1}+k_{d} \dot{z}_{1}+k_{s} z_{1}=0 \ldots \ldots \ldots \ldots \ldots \ldots \\
& k_{d}=k_{d 1}+k_{d 2} \ldots(8), k_{s}=k_{s 1}+k_{s 2} \ldots
\end{aligned}
$$
但し,

$$
\begin{aligned}
& k_{d 1}=-\left[\frac{\partial}{\partial v_{z}} F_{L}\left(h, v_{z}, I_{s c 1}, \cdots, I_{s c p}\right)\right]_{v_{z}=0} \\
& k_{d 2}=-\sum_{i=1}^{P_{s c}}\left[\frac{\partial}{\partial I_{s c i}} F_{L}\left(h, 0, I_{s c 1}, \cdots, I_{s c p}\right)\right] \\
& \times\left[\frac{\partial}{\partial v_{z}} I_{s c i}\left(h, v_{z}\right)\right]_{v_{z}=0}
\end{aligned}
$$

まだ

$$
\begin{aligned}
k_{s 1}= & -\frac{\partial}{\partial h} F_{L}\left(h, 0, I_{s c \mathrm{t}}, \cdots, I_{s c p}\right) \ldots \ldots \\
k_{s 2}= & -\sum_{i=1}^{P_{s c}}\left[\frac{\partial}{\partial I_{s c i}} F_{L}\left(h, 0, I_{s c 1}, \cdots, I_{s c p}\right)\right] \\
& \times\left[\frac{\partial}{\partial h} I_{s c i}(h, 0)\right] \ldots \ldots \ldots \ldots \ldots \ldots
\end{aligned}
$$

(8)，(10)，(11) 式が磁気ダンピング係数，(9), (12)，(13) 式加磁気ば祖係数である。(11)，(13)式加ら 明らかなように， $k_{d 2}$ と $k_{s 2}$ は上下振動による車上コ イル電流の変化に依存する成分で, 複雑なうず笔流現 象から結果するものである。また(7)式で, $-k_{d} \dot{z}_{1}$ が上下振動の磁気ダンピング力を意味する。

(10)，(11)式枯，磁気ダンピング係数 $k_{d}$ が，車上 コイルを浮上高さ $h$ に静此させ，シート軌道を $z$ 方向 に一定速度 $-v_{z}$ で動かす仮定する定常状態解析加 ら誘導され得るととを示している。従って，上下方向 の磁気ダンピング係数は次章の数学的モデルを用いて 解析することができる。

\section{3. 理 諭}

〈3.1〉解析モデル 第2図は，前章に徉い磁気 ダンピング係数とばね係数を空間高謂波解析法によっ て謣導するための解析モデルと座標系を示す。 $x$ 軸は 車上コイルの下方 $h+d の$ 位直に固定した静止座標 で， $x^{\prime}$ 軸は車上コイルに固定した移動座標である。 第 2 図の (a)ट(b)はそれぞれ車上ニイルの $x^{\prime}$ 方向! とy方向の周期的配置の一部断面とその起磁力分布を 示す。解析の簡単化のために，次のととが仮定されて いる。

（1）車上コイル群は有限個 ( $P_{s c}$ 個) の方形コイ ルからなる直線状配列とし，すへてのコイル電流は長 さ $l_{s c} \times$ 幅 $w_{s c}$ の方形ループの線状電流で表わす。

（2）車上コイル群は一定速度 $v_{2}$ で $x$ 方向に走行 しており， $x^{\prime}$ 方向に $2 L_{1}, y$ 方向に $2 w_{p}$ の周期を むって配置される。

(3) 導電率 $\sigma$ のシート轨道は, $x$ 亡y方向に無限 に広く, 軌道の下側表面が $z=0$ 平面に一致する位置 において $z$ 方向に一定速度ーvョで動いているとする。

（4）シート軌道に諉導されるうず電流の表皮効果 は無視する。

なお，仅定(2)に関して，x方向の車上コイル群間: 隔 $l$ 。磁気的相互作用が無視できる程度に十分長く 


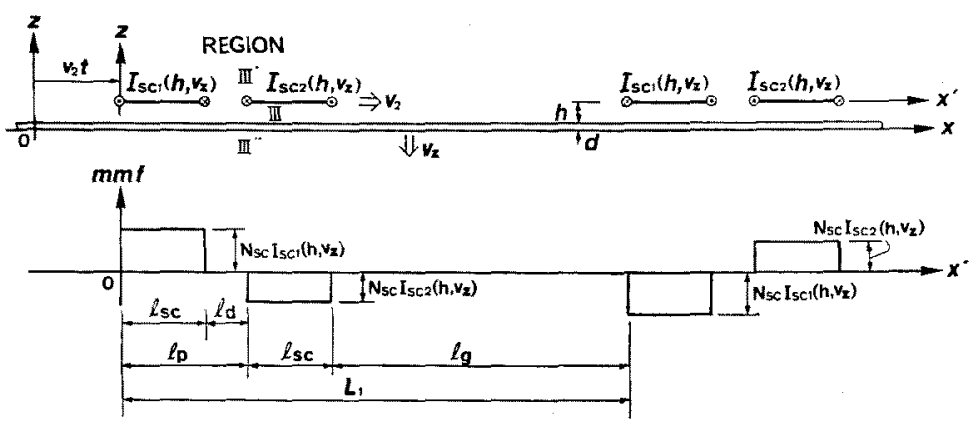

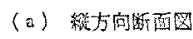

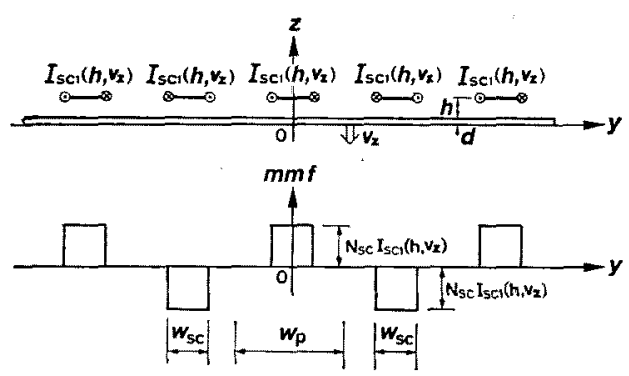

(b) 横方向断面图

第 2 図 数学的モデルと起磁力分布

Fig. 2. Mathematical model and $\mathrm{mmf}$ distributions.

選定するととによって端部効果が考慮できる。また 適当な場抗比を得る目的で，シート幅が一般化 $w_{p}=$ $2 w_{s c}$ 程度に選ばれる(4)(6) ととを前提とすれば， $y$ 万 向の車上コイル間磁気的相互作用む無視できシート䩔 道の有限幅効果が若虑できる。

〈3.2〉 車上コイル電流に等価な表面電流 本解 析では車上コイル電流を Current Sheet で置き換え て取り报うが，之の表面電流山次の上うに求まる。

列車進行方向に向加って最後加ら第 $i$ 番目のコイル 笔流を $I_{s c i}\left(h, v_{z}\right)$ とすれば，第 2 四の車上コイルが作 万起磁力は，移動塺標 $x^{\prime}$ 亿関して次式の上うに二重 フーリエ級数展開される。

$$
\begin{array}{rl}
f\left(x^{\prime}, y\right)= & \sum_{m} \sum_{n} \frac{16}{\pi^{2}} N_{s c} \frac{1}{m n} k_{w, m n} \cos k_{y n} y \\
& \times \sum_{i=1}^{P_{s c}}(\mp 1)^{i-1} I_{s c i}\left(h, v_{z}\right) \cos k_{x m} \\
& \times\left[x^{\prime}-\left\{(i-1) l_{p}+\frac{l_{s c}}{2}\right\}\right] \\
& (m=1,3, \cdots, n=1,3, \ldots) \ldots(14) \\
x^{\prime}=x-v_{2} & t \ldots \ldots \ldots \ldots \ldots \ldots \ldots \ldots \ldots(15)
\end{array}
$$

但し,

$$
L_{1}=\left(P_{s c}-1\right) l_{p}+l_{s c}+l_{g}, l_{p}=l_{s c}+l_{d},
$$

昭 $54-12$

$$
\begin{aligned}
& k_{w, m n}=k_{p m} k_{p n}, \\
& k_{p m}=\sin k_{x m} l_{s c} / 2, \\
& k_{p n}=\sin k_{y n} l_{s c} / 2, \\
& k_{x m}=m \pi / L_{1}, \\
& k_{y n}=n \pi / w_{p}
\end{aligned}
$$

また，Nscは軲上コイル 1 個の巻数であり,(14)式 の複号のう方一符号は交番 極性配列，十符号は同極性 配列の場合である。

(1) 式と等価な起磁力在作る表面電流 $j_{1 v}{ }^{\prime}$ は，複 素数表示すると, $j_{1 y^{\prime}}=\operatorname{Re}\left(j_{1 y}\right)=-\partial f\left(x^{\prime}, y\right) / \partial x^{\prime}$ の 関倸から

$$
\begin{aligned}
& j_{1 y}= \sum_{m} \sum_{n} J_{1 y, m n}\left(h, v_{z}\right) \cos k_{y n} y \\
& \times \varepsilon^{j k_{s m}\left(v_{z} t-x\right)} \ldots \ldots \ldots \ldots \ldots \ldots . \ldots \ldots \ldots \\
& J_{1 y, m n}\left(h, v_{z}\right) \\
&= j \frac{16}{\pi^{2}} N_{s c} \frac{k_{w, m n}}{m n} k_{I m} \sum_{i=1}^{P_{s c}}(\mp 1)^{i-1} \\
& \times I_{s c i}\left(h, v_{z}\right) \varepsilon^{j k_{x m}}\left\{(i-1) l_{b}+l_{s c} / 2\right\} .
\end{aligned}
$$

〈3.3〉基礎方程式之境界条件低周波数低速度 の磁気浮上系㹥準静的なマクスウェルの電磁方程式で 記述でき，磁気べクトルポテンシャル $\boldsymbol{A}$ 省入する 之，次の基礎方程式を得る。

$$
\nabla^{2} \boldsymbol{A}=-\mu \boldsymbol{i}
$$

但し,

$$
\begin{aligned}
& \boldsymbol{B}=\nabla \times \boldsymbol{A}, \quad \boldsymbol{B}=\left(B_{x}, B_{y}, B_{z}\right) \\
& \nabla \cdot \boldsymbol{A}=0 \quad \ldots \ldots \ldots \ldots \ldots \ldots \ldots \ldots \ldots \ldots \ldots \ldots \ldots \ldots
\end{aligned}
$$

シート軌道に関す歹構成方程式は，軌道の速度を $v$ とすれば,

$$
\boldsymbol{i}=\sigma(\boldsymbol{E}+\boldsymbol{v} \times \boldsymbol{B})
$$

但し，

$$
v=\left(0,0,-v_{z}\right)
$$

シート軌道之Current Sheet 除〈領域 III, 而', 形 ${ }^{\prime \prime}$

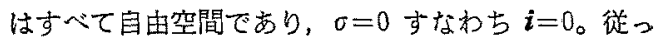
て，てれらの空気領域では，

$$
\nabla^{2} \boldsymbol{A}=0
$$

第 2 図の解析モデルでは，すべての電流が $x$ 成分之 $y$ 成分だけであるから，(18)式より，

$$
\boldsymbol{A}=\left(A_{x}, A_{y}, 0\right)
$$

また第 2 図の問題では，電界の強さ $E$ は,

$$
\boldsymbol{E}=-\frac{\partial \boldsymbol{A}}{\partial t}, \quad \boldsymbol{E}=\left(E_{x}, E_{y}, 0\right)
$$

$A_{x}$ と $A_{y}$ は (20), (25)式の関係を与えれば, un- 
coupled であってどちらか一方が得られると他方は (20)式から求かられるので，ここでは $A_{y}$ だけに関し て解新する。

各境界面で渾足すべき条件は，領域 III，䎟，卭”の ベクトルポテンシャルの $y$ 成分 $A_{y}$ II, $A_{y} \mathbb{M}^{\prime}, A_{y} \mathbb{M}^{\prime \prime}$ に ついてめ下のように与えられる。

（a）領域 III' ${ }^{\prime}$ III の境界： $z=h$

$$
\begin{aligned}
& A_{y} \text { III }^{\prime}=A_{y} \text { II } \\
& -\frac{1}{\mu_{0}} \frac{\partial A_{y} \text { II' }^{\prime}}{\partial z}+\frac{1}{\mu_{0}} \frac{\partial A_{y} \text { II }}{\partial z}=j_{1 y}
\end{aligned}
$$

（b）領域 III と III" の境界： $z=0$ この境界面 は $z$ 方向に一泟で移動するが，境界条件は境界の速 度に依存甘ず静止境界の場合之同形で与えられる。

$$
\begin{aligned}
& A_{y} \mathrm{II}=A_{y} \mathrm{II}^{\prime \prime} \\
& -\frac{1}{\mu_{0}} \frac{\partial A_{y} \mathbb{I I}}{\partial z}+\frac{1}{\mu_{0}} \frac{\partial A_{y} \mathbb{M}^{\prime \prime}}{\partial z}=j_{2 y}
\end{aligned}
$$

(27b) 式の $j_{2}$ はシート軌道の表面電流で, 纳定 （4）により表皮効果を無視するので，(19)，(21)，(22)，

(25)式を用いて次式で与えるてとができる。

$$
\begin{aligned}
j_{2 y} & =d \sigma\left[E_{y}-v_{z} B_{x} \mathbb{I I}\right]_{z=0} \\
& =d \sigma\left[-\frac{\partial A_{y} \mathbb{I I}}{\partial t}+v_{z} \frac{\partial A_{y} \mathbb{I I}}{\partial z}\right]_{z=0} \cdots
\end{aligned}
$$

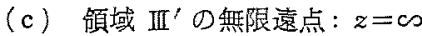

$$
A_{y} \text { III' }^{\prime}=0
$$

（d） 領域 III" $の$ 無限遠点： $z=-\infty$

$$
A_{y} \mathbb{I I}^{\prime \prime}=0
$$

〈3.5〉各領域のベクトルポテンシャル $\quad A_{y}$ III, $A_{y} \mathrm{I}^{\prime}, A_{y} \mathrm{~W}^{\prime \prime}$ は $x, y, t$ 亿関して(16)式の表面電流之同 形の変数分離形で表わされ，(23)式を解くとそれぞれ 次式となる。

$$
\begin{aligned}
A_{y} \mathbb{W}= & \sum_{m} \sum_{n}\left(C_{m n} \mathbb{I} \varepsilon^{k_{m n} z}+D_{m n} \mathbb{W} \varepsilon^{-k_{m n n} z}\right) \\
& \times \cos k_{y n} y \cdot \varepsilon^{j k_{x m}\left(v_{z} t-x\right)} \quad \ldots \ldots \ldots . .
\end{aligned}
$$

(29) 式の条件加ら

$$
\begin{aligned}
A_{y} \mathbb{E}^{\prime}= & \sum_{m} \sum_{n} D_{m n} \mathbb{W}^{\prime} \varepsilon^{-k_{m n} z} \cos k_{y n} y \\
& \times \varepsilon^{j k_{x m}\left(v_{2} t-x\right)} \quad \ldots \ldots \ldots \ldots \ldots \ldots \ldots \ldots \ldots \ldots
\end{aligned}
$$

(30)式の条件加ら

$$
\begin{aligned}
& A_{y} \text { III }^{\prime \prime}=\sum_{m} \sum_{n} C_{m n} \text { W" }^{\prime \prime} \varepsilon^{k_{m n} z} \cos k_{y n} y \\
& \times \varepsilon^{j k_{x m}\left(v_{2} t-x\right)}
\end{aligned}
$$

但L，

$$
k_{m n}=\sqrt{k_{x m^{2}}+k_{y n}{ }^{2}}
$$

(31) ～(33) 式の未知数を(26)，(27) 式の条件加ら決 定すると，(31)式は，

$$
\begin{aligned}
A_{y} \mathrm{II}= & \sum_{m} \sum_{n} \frac{1}{2} \mu_{0} \frac{J_{1 y, m n}\left(h, v_{z}\right)}{k_{m n}}\left\{\varepsilon^{k_{m n}(z-h)}\right. \\
& -\frac{v_{2}+j \frac{1}{2} \mu_{0} \sigma d v_{z} v_{m n}}{v_{2}-j\left(1+\frac{1}{2} \mu_{0} \sigma d v_{z}\right) v_{m n}} \\
& \left.\times \varepsilon^{-k_{m n}(z+h)}\right\} \cos k_{y n} y \cdot \varepsilon j k_{x m}\left(v_{z} t-x\right) \ldots(3
\end{aligned}
$$

またベクトルポテンシャルの $x$ 成分 $A_{x}$ II 仙 (20) 式汃 b

$$
\begin{aligned}
A_{x} \underline{\text { III }}= & \sum_{m} \sum_{n} j \frac{1}{2} \mu_{0} \frac{J_{1 y, m n}\left(h, v_{z}\right)}{k_{m n}} \frac{k_{y n}}{k_{x m}}\left\{\varepsilon^{k_{m n}(z-h)}\right. \\
& \frac{v_{2}+j \frac{1}{2} \mu_{0} \sigma d v_{z} v_{m n}}{v_{2}-j\left(1+\frac{1}{2} \mu_{0} \sigma d v_{z}\right) v_{m n}} \\
& \left.\times \varepsilon^{-k_{m n}(z+h)}\right\} \sin k_{y n} y \cdot \varepsilon^{j k_{x m}\left(v_{z} t-x\right)}
\end{aligned}
$$

但し, $v_{m n}=\left(2 k_{m n} / \mu_{0} \sigma d k_{x m}\right)$

〈3.5〉磁気ダンピング係数とばね係数

（a）永久電流モードの場合 第 2 図の車上コイ 儿群牦く浮上力は, シート軌道表面 $z=0$ 亿怙ける 磁束密度 $\boldsymbol{B}_{2} \mathrm{II}=\left(B_{x 2} \mathrm{II}, B_{y_{2}} \mathrm{II}, B_{x 2} \mathrm{II}\right)$ で表示するマク スウェルの磁気㐫力テンソルを用いて, シート軌道に 㗢く $z$ 方向の力の反作用力として次式で求まる。な

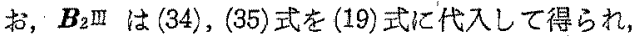
*结複素共役である。

$$
\begin{aligned}
& F_{L}\left\{h, v_{z}, I_{s c 1}\left(h, v_{z}\right), \cdots, I_{s c p}\left(h, v_{z}\right)\right] \\
& =\frac{1}{16 \mu_{0}} \int_{-w_{p}}^{w_{p}} \int_{0}^{2 L_{1}}\left(B_{x 2} \mathbb{M} B_{x 2} \mathbb{I}^{*}\right. \\
& \left.+B_{y 2}{ }^{\text {II }} B_{y 2} \text { II }^{*}-B_{z 2} \text { ㅍ } B_{z 2} \text { WL }^{*}\right) d x^{\prime} d y \\
& =\sum_{m} \sum_{n} \frac{32}{\pi^{4}} \mu_{0} N_{s c}{ }^{2}\left\{I_{s c}\left(h, v_{z}\right)\right\}^{2}\left(L_{1} w_{p}\right) \\
& \times\left(\frac{k_{w, m n}}{m n}\right)^{2} k_{m n^{2}} \\
& x \frac{v_{2}{ }^{2}-\frac{1}{2} \mu_{0} \sigma d v_{z}\left(1+\frac{1}{2} \mu_{0} \sigma d v_{z}\right) v_{m n}{ }^{2}}{v_{2}{ }^{2}+\left(1+\frac{1}{2} \mu_{0} \sigma d v_{z}\right)^{2} v_{m n}{ }^{2}} \\
& \times \varepsilon^{-2 k_{m n} h} \\
& \left\{I_{s c}\left(h, v_{z}\right)\right\}^{2} \\
& =\sum_{i=1}^{P_{s c}} \sum_{j=1}^{P_{s c}}(\mp 1)^{i+j} I_{s c j}\left(h, v_{z}\right) I_{s c j}\left(h, v_{z}\right) \\
& \times \cos (i-j) k_{x m} l_{p}
\end{aligned}
$$

(37) 式のコイル電流 $I_{s c i}\left(h, v_{z}\right)$ は，付録に示す事上 
コイルの銷交磁束 $\lambda_{i}$ が, 列車速度 $v_{2}$ とシート軌道 の $z$ 方向速度 $-v_{z}$ に全く無関係に一定に保持される という永久電流モードの条件

$\lambda_{i}=\lambda_{i}(0)=$ 列車静止時の鎖交磁束

加ら次式で求められる。

$$
I_{s c i}\left(h, v_{z}\right)=\frac{\Delta_{i}\left(h, v_{z}\right)}{\Delta\left(h, v_{z}\right)}
$$

但し， $L_{i}\left(h, v_{z}\right)$ は(付 2 ) 式を参照する上，

$$
\begin{aligned}
& \Delta\left(h, v_{z}\right)=\operatorname{det}\left|L_{i j}\left(h, v_{z}\right)\right|
\end{aligned}
$$

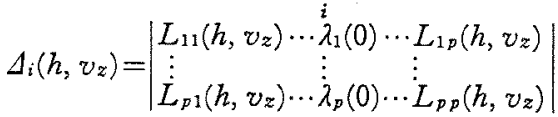

また, 列車静止時 $\left(v_{2}=0, v_{x}=0\right)$ の励磁電流を $I_{s \in 0}$ とすれ代，(付 1) 式加ら

$$
\begin{aligned}
& \lambda_{i}(0)=\sum_{m} \sum_{n} \frac{32}{\pi^{4}} \mu_{0} N_{s c^{2}} I_{s c 0}\left(L_{1} w_{p}\right)\left(\frac{k_{w, m n}}{m n}\right)^{2} \\
& \times k_{m n} k_{L p m} \\
& \times\left\{\begin{array}{c}
\cos \left(P_{s c}-2 i+1\right) k_{x m} l_{p} / 2 \\
\left(P_{s c}=\text { 奇数 }\right) \\
\sin \left(P_{s c}-2 i+1\right) k_{x m} l_{p} / 2
\end{array}\right\} \\
& P_{s c}=\text { (偶数) } \\
& \cos \left(P_{s c}-2 i+1\right) k_{x m} l_{p} / 2 \text { 同極性 } \\
& k_{L p m}=\left\{\begin{array}{ll}
\frac{\cos P_{s c} k_{x m} l_{p} / 2}{\cos k_{x m} l_{p} / 2}\left(P_{s c}=\text { 奇数 }\right) \\
\frac{\sin P_{s c} k_{x m} l_{p} / 2}{\cos k_{x m} l_{p} / 2}\left(P_{s c}=\text { 偶数 }\right)
\end{array}\right\} \begin{array}{l}
\text { 交粰 } \\
\frac{\sin P_{s c} k_{x m} l_{p} / 2}{\sin k_{x m} l_{p} / 2}
\end{array}
\end{aligned}
$$

浮上走行の平衡点に斿いては，

$$
v_{z}=0, I_{s c i}=I_{s c i}(h, 0)
$$

であることを考慮に入れて，(36)式を(10)〜 (13)式に 代入する上，永久電流モードに捛りる磁気ダンピング 係数こばね係数は（8)，(9) 式に從って以下のように

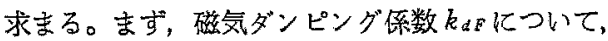

$$
k_{d F}=k_{d F 1}+k_{d F 2}
$$

(10)式は $k_{d 1}$ の代わりに $k_{d F 1}$ と表わして,

$$
\begin{aligned}
k_{d F 1}= & \sum_{m} \sum_{n} \frac{16}{\pi^{4}} \mu_{0} N_{s c^{2}} I_{s c^{2}}\left(L_{1} w_{p}\right) \mu_{0} \sigma d \\
& \times\left(\frac{k_{w, m n}}{m n}\right)^{2} k_{m n^{2}} \frac{\left(3 v_{2}^{2}+v_{m n}{ }^{2}\right) v_{m n}{ }^{2}}{\left(v^{2}+v_{m n}\right)^{2}} \\
& \times \varepsilon^{-2 k_{m n} h} \ldots \ldots \ldots \ldots \ldots \ldots \ldots \ldots \ldots
\end{aligned}
$$

但し,

$$
I_{s c}{ }^{2}=\left\{I_{s c}(h, 0)\right\}^{2}
$$

(11)式は $k_{d 2}$ の代わりに $k_{d F 2}$ と表わして,

$$
\begin{aligned}
& k_{d F 2}=\sum_{i=1}^{P_{s c}} A_{i} B_{i} \ldots \ldots \ldots \ldots \ldots \ldots \ldots . . . \\
& A_{i}=\sum_{m} \sum_{n} \frac{64}{\pi^{4}} \mu_{0} N_{s c^{2} I_{s c}(i)\left(L_{1} w_{p}\right)} \\
& \times\left(\frac{k_{w, m n}}{m n}\right)^{2} k_{m n^{2}} \frac{v_{2}{ }^{2}}{v_{2}^{2}+v_{m n}^{2}} \varepsilon^{-2 k_{m h} h} . \\
& B_{i}=\frac{\dot{\Delta}_{v} \Delta_{i}-\dot{\Delta}_{i, v} \Delta}{\Delta^{2}} \ldots \ldots \ldots \ldots \ldots \ldots \ldots . .
\end{aligned}
$$

但し，

$$
I_{s c}(i)=\sum_{\nu=1}^{P_{s c}}(\mp 1)^{\nu-i} I_{s c} \cos (\nu-i) k_{x m} l_{p}
$$

$$
\Delta=\Delta(h, 0)=\operatorname{det}\left|L_{i j}\right|
$$

$\Delta_{i}=\Delta_{i}(h, 0)$

$$
\begin{aligned}
& \dot{J}_{v}=\sum_{\nu=1}^{P_{s c}}\left|\begin{array}{ccc}
L_{11} & \cdots & L_{1 p} \\
\vdots & & \\
\dot{D}_{\nu 1} & \cdots & D_{p} p \\
\vdots & & \\
L_{p 1} & \cdots & L_{p p}
\end{array}\right|
\end{aligned}
$$

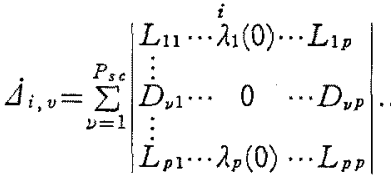

$$
\begin{aligned}
D_{i j}= & (\mp 1)^{j-1} \sum_{m} \sum_{n} \frac{32}{\pi^{4}} \mu_{0} N_{s c}^{2}\left(L_{1} w_{p}\right) \\
& \times\left(\frac{k_{w, m n}}{m n}\right)^{2} k_{m n}\left\{g_{R v} \cos (i-j) k_{x m} l_{p}\right. \\
& \left.+g_{r v} \sin (i-j) k_{x m} l_{p}\right\} \ldots \ldots \ldots \ldots(54)
\end{aligned}
$$

$$
g_{\bar{R}}=\frac{1}{2} \mu_{0} \sigma d \frac{\left(3 v_{2}^{2}+v_{m n}^{2}\right) v_{m n^{2}}^{2}}{\left(v_{2}^{2}+v_{m n}\right)^{2}} \varepsilon^{-2 k_{m n} h}
$$

$$
g_{1 v}=-\mu_{0} \sigma d \frac{v_{2}^{3} v_{m n}}{\left(v_{2}^{2}+v_{m n}\right)^{2}} \varepsilon^{-2 k_{m n} h}
$$

また，磁気恔称係数 $k_{s} F$ について

$$
k_{S F}=k_{S F 1}+k_{S F 2}
$$

(12)式は $k_{s 1}$ の代bりに $k_{s F 1}$ と表わして,

$$
\begin{aligned}
k_{s F 1}= & \sum_{m} \sum_{n} \frac{64}{\pi^{4}} \mu_{0} N_{s c^{2}} I_{s c^{2}}\left(L_{1} w_{p}\right) \\
& \times\left(\frac{k_{w, m n}}{m n}\right)^{2} k_{m n}{ }^{3} \frac{v_{2}^{2}}{v_{2}^{2}+v_{m n}{ }^{2}} \varepsilon^{-2 k_{m n} h}
\end{aligned}
$$

(13)式は $k_{s 2}$ の代わりに $k_{s F 2}$ と表わして，

$$
k_{s F 2}=\sum_{i=1}^{P_{s t}} A_{i} C_{i}
$$




$$
C_{i}=\frac{\dot{\Delta}_{h} \Delta_{i}-\dot{\Delta}_{i, h} \Delta}{\Delta^{2}}
$$

但し，

$$
\begin{aligned}
& \dot{\Delta}_{h}=\sum_{\nu=1}^{P_{s c}}\left|\begin{array}{ccc}
L_{11} & \cdots & L_{1 p} \\
\vdots & & \vdots \\
E_{\nu 1} & \cdots & E_{\nu p} \\
\vdots & & \\
\dot{L}_{p 1} & \cdots & L_{p p}
\end{array}\right|
\end{aligned}
$$

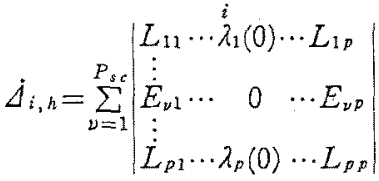

$$
\begin{aligned}
& E_{i j}=(\mp 1)^{j-1} \sum_{m} \sum_{n} \frac{32}{\pi^{4}} \mu_{0} N_{s c^{2}}\left(L_{1} w_{p}\right) \\
& \times\left(\frac{k_{w, m n}}{m n}\right)^{2} k_{m n}\left\{g_{R h} \cos (i-j) k_{x m} l_{p}\right. \\
& \left.+g_{I h} \sin (i-j) k_{x m} l_{p}\right\} \\
& g_{R h}=2 k_{m n} \frac{v_{2}^{2}}{v_{2}^{2}+v_{m n}{ }^{2}} \varepsilon^{-2 k_{m n} h} \\
& g_{I h}=2 k_{m n} \frac{v_{2} v_{m n}}{v_{2}^{2}+v_{m n}^{2}} \varepsilon^{-2 k_{m} h}
\end{aligned}
$$

（b）定電流モードの場合 すべての車上コイル 電流住列車静止時の励磁電流 $I_{s c 0}$ K等しいので, こ の場合の磁気ダンピング係数とばね係数をそれぞれ $k_{a t,}, k_{s t}$ で表わせば，（11)式と(13)式加ら

$$
k_{d F 2}=0, k_{s F 2}=0 \text {. }
$$
となり

$$
\begin{aligned}
k_{d I}= & {\left[k_{d F I}\right] I_{s c i}=I_{s c 0} } \\
= & \sum_{m} \sum_{n} \frac{16}{\pi^{4}} \mu_{0} N_{s c^{2}} I_{s c 0^{2}}\left(L_{1} w_{p}\right) \mu_{0} \sigma d \\
& \times\left(\frac{k_{w, m n} k_{L p m}}{m n}\right)^{2} k_{m n^{2}} \frac{\left(3 v_{2}^{2}+v_{m n^{2}}\right) v_{m n}^{2}}{\left(v_{2}^{2}+v_{m n}\right)^{2}} \\
& \times \varepsilon^{-2 k_{m n} h} \ldots \ldots \ldots \ldots \ldots \ldots \ldots \ldots(66) \\
k_{s I}= & {\left[k_{s F 1] I_{s c i}=I_{s c 0}}\right.} \\
= & \sum_{m} \sum_{n} \frac{64}{\pi^{4}} \mu_{0} N_{s c^{2}} I_{s c 0^{2}}\left(L_{1} w_{p}\right) \\
& \times\left(\frac{k_{w, m n} k_{L p m}}{m n}\right)^{2} k_{m n^{3}} \frac{v_{2}{ }^{2}}{v_{2}^{2}+v_{m n}{ }^{2}} \varepsilon^{-2 k_{m n} h}
\end{aligned}
$$

(66)式によ㣗ば，定電流モードの磁気ダンピング係 数 $k_{d I}$ は常に正であることが明白である。

\section{4. 数值例による検討}

本章では，車上コイルが交番極性配置である場合の 磁気ダンピング係数とばね係数の速度依存性を，第 1
表の諸元を用いて検討する。直線配列した片㑡車上コ イルの個数 $P_{s c}$ が 1,2,3,4 個の場合亡列車端端部効果 を無視した場合について数値計算を行ない，端部効果 の影響，永久電流モードと定電流モードによる墥いな どを定量的に明らかにする。なお，第 1 表の諸元はル 一プ轨道の文献(1)に基づくあのであるが，アルミニ ウムシートの厚さ $d$ はシート幅 $w_{p}=2 w_{s c}$ と仮定 し、ループ軦道と同じアルミニウム量となるように決 定した。

第 3 図は定電流モードの磁気ダンピング係数 $k_{d I}$ を 車上コイル 1 個あたりで示し，比較のためにループ軌 道の場合を引用している(1)(2)。シート軌道の場合，コ イル個数 $P_{s c}$ Kかかわらず常に正の磁気ダンピングが 存在する。低速 $(50 \mathrm{~km} / \mathrm{h}$ 近傍) で磁気ダンピングの ピークがあり，それ以上の速度では速度と共に急激に 減少するが，高速領域 $(300 \sim 500 \mathrm{~km} / \mathrm{h})$ でも相当強い， 磁気ダンピングが存在することがわかる。こ机はルー プ軌道との本質的な違いである。

第 4 図々第 5 図は，永久電流モードの磁気ダンピン 名係数 $k_{d F} の$ 二つの成分 $k_{d F 1}$ と $k_{d F 2}$ の速度存在 性を車上コイル1個むたりで示す。 $k_{d}$ 的は車両の上 下振動佂接起因して発生するシート軌道のうず電流 損に依存する磁気ダンピング保数で方って，全体的に 海第 3 图の $k_{d I}$ とよく似た速度依存特性を示す。しか し，永久電流モードの場合各車上コイル電流は第 6 図 のようにそれぞれ列車速度 v2 上共に增大する(7)た

\begin{tabular}{|c|c|}
\hline 超電導䉕磁石 & 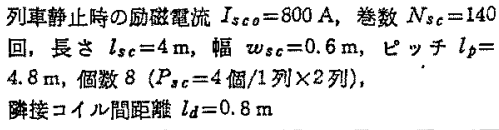 \\
\hline 浮上高さ & $h=25 \mathrm{~cm}$ \\
\hline$*-1$ 䉼道 & 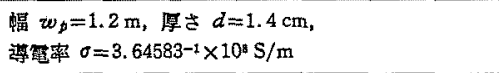 \\
\hline
\end{tabular}
め, $k_{d I I}$ 之は列車静止時 $\left(v_{2}=0\right)$ でだけ一致し速度が 増すに従って差違が顕著になる。高速領域では，各車 上コイル電流の橧加加列車静止時電流 $I_{s c 0}$ の $10 \sim 15$ \%にも達するため, $k_{d F 1}$ は $k_{d I}$ の $30 \%$ 增しの強い 磁気ダンピングを示す。また， $k_{d F 2}$ は上下振動によ るうず電流の反作用磁束を打消すための車上コイル電 流の変化に起因して発生するうず電流損に依存するす ので， $k_{d F_{1}}$ とは異質の磁気ダンピング係数であって， 列車速度起電力が存在しない列車静止時には $k_{d F 2}=0$ となる。 $k_{d F 2}$ も常に正で， $100 \mathrm{~km} / \mathrm{h}$ 近傍にピークを もち，それ以上の速度では速度と共汇減少するが，

第 1 表 磁気浮上系の諸元

Table 1. Design parameters of Maglev system. 


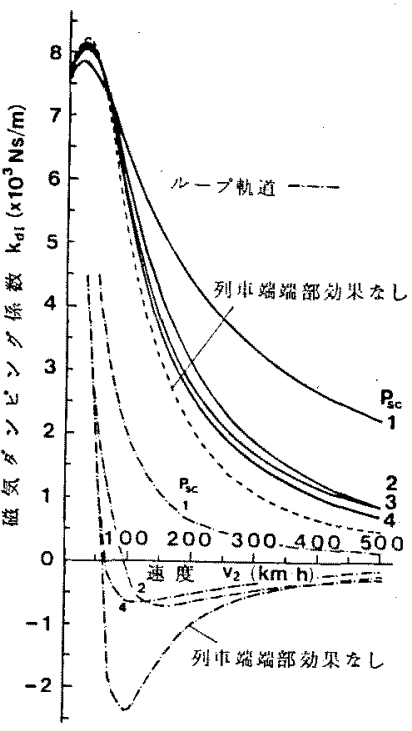

第3图 定電流モードにおける磁 気ダンピング係数の速度依存性（車 上コイル1個あたり)

Fig. 3. Velocity-dependence of magnetic damping coefficient in constant-current mode.

$k_{d I}$ や $k_{d F 1}$ に比べると，その減少傾向ははるかに緩 やかで，高速領域でも $k_{d I}$ の $30 \%$ 程度の䛧をむつた め決して無視できない。

第 3 园一第 5 図加ら明らかなように，列車端端部効 果は列車速度が高いにど両モードの磁兴ダンピングを 强める作用をする。特にコイル数 $P_{s c}=1$ の場合, 解 析に端部效果を考慮するか否かでは磁気ダンピングの 算定に本啠的高違いがある。 $P_{s c}=2$ の場合，前後の 車上コイル間の磁気的結合が非常に強いため, 端部効 果の影皕は急激に減少して，磁気的ダンピングが $P_{s c}$ $=1$ の場合の半分义下と非常に弱くなる。 $P_{s c}$ を 3,4 個と増せば，端部効果の影響は更に少なくはなるが， それり上 $P_{s c}$ を增してすコイル1個むたりの磁気ダン ピングはほとんど変わらない。

第 7 図と第 8 困は磁気ダンピング係数とばね係数の 永久電流モードと定電流モートによる違いを明らかに する委ので，車上コイルが車両の両側に $P_{s c}$ 個ずつあ る1車画あたりで示した。第 7 図に示す両モードの磁 気ダンピング係数 $k_{d} F$ と $k_{d l}$ は, 列車静止時では一 致してむ速度加增すと共に大きく違ってくる。列車の 巡航速度 $500 \mathrm{~km} / \mathrm{h}$ において，kdFはイル数 $P_{s c}$ に むわずか化依存するが， $k_{d 1}$ よりも50〜60\% も大き く，両モードの本質的な違いが明らかである。

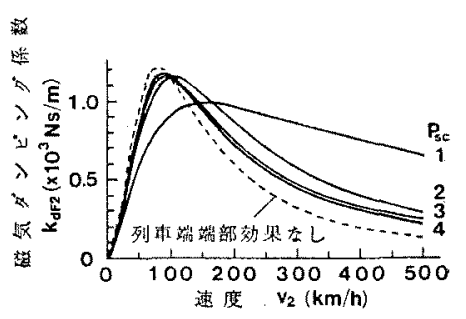

第 5 図 永久㲠流モードに术りる磁気 $P_{\mathrm{sc}}$ ダンピング係数 $k_{d F 2}$ の速度依存性（車 上コイル 1 個むたり)

Fig. 5. Velocity-dependence of mag2 netic damping coefficient $k_{d F}$ in persistent-current mode.

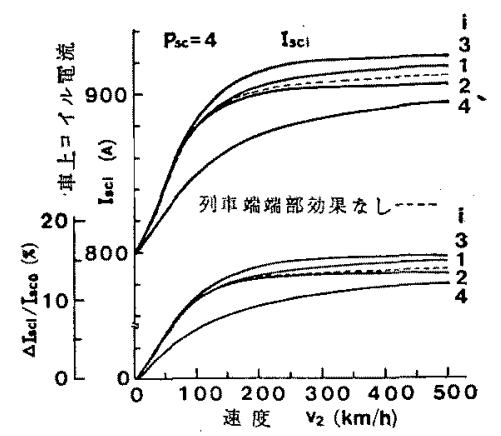

第 6 图 事上コイル電流の速度依存性 Fig. 6. Velocity-dependence of vehicle coil current.

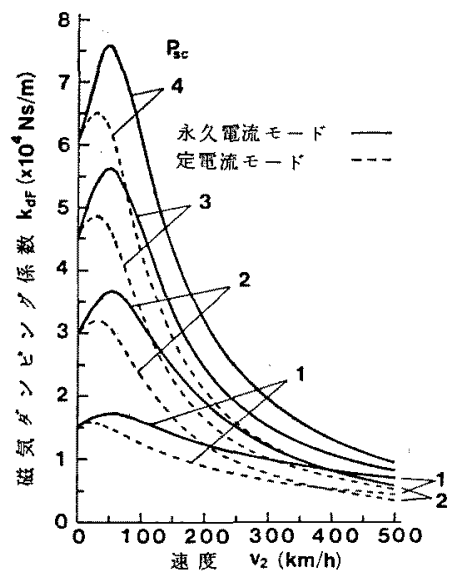

第 7 図 永久電流モードにおける磁気ダンピング 係数 $k_{d F}$ の速度依存性 (車上コイル2P $s c$ 個あたり)

Fig. 7. Velocity-dependece of magnetic damping coefficient $k_{d} F$ in persistent-current mode.

第 8 図は両モードの磁気ばね係数 $k_{s F}$ 亡 $k_{s I}$ を示 すが，列車速度が高いほど両モードの違いは著しく， 


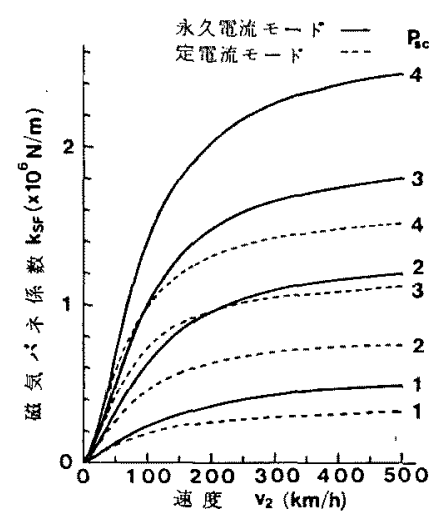

第 8 图 永久電流モードに和ける磁䒝ばね係数 $k_{s}$ の速度依存性（車上コイル $2 P_{s 。}$ 個あたり）

Fig. 8. Velocity-dependence of magnetic stiffness coefficient $k_{S F}$ in persistent-current mode.

高速項域では $k_{s}$ が $k_{s} I$ よりもやはり 50〜60\%む 大きい。端部效果は雨モードの磁気ば拜数老小さく するように作用し，端部効果の最も大きい $500 \mathrm{~km} / \mathrm{h}$ において，端部效果による磁気ば称係数の減少率は $P_{s c}=1$ 個の場合 $20 \%$ で比較的大きいか;, $P_{s c \geqq 2}$ の 場合 $5 \%$ 以下と非常に小さい。

\section{5. むすび}

シート軌道超電導磁気浮上系の事両上下振動に関す る磁気ダンビング係数しばね係数の理諭式導出に際し て，列車端端部効果を比較的簡便に取扱える空間高調 波解析法を提案し，実際の励磁モードである永久電流 モードに执いて，車上コイルが交番極性放よび同極性 配列の場合の解析を行なった。本理論式によって，交 番極性配列の場合の両係数を定量的に検討した。その 結果，明らかになった主要な点心次のようである。

(1) 磁気ダンピング係数は，定電流モードと永久 電流モードの両励磁モードに打いて常に正で，本浮上 系はすべての列車速度にわたって動的に安定である。

（2）永久電流モードの磁気ダンピング係数は巡航 速度 $500 \mathrm{~km} / \mathrm{h}$ 亿招いてすかなり大きい檤を示すがま だ適度な乗り心地を得るほどではない。しかし後同 極性配列の場合 ${ }^{(8)}$ あ含め更深い検討の価值がある。

（3）永久電流モードの磁気ダンピング係数とばね 係数は，定電流モードのそれらに比べ非常に大きく， 再励磁モードには本質的な違いがある。

（4）定電流モードの場合，シート軌道方式は同量 アルミニウムで作るループ軌道方式よりもはるが強 い磁気ダンピング効果を示す。
（5）列車端端部効果は両励磁モードの磁気ダンピ ングを非常に強める作用をするため，これを無視でき ない。一方，磁気ば权係数に対する端部効果は逆にと れを弱めるがはとんど器梘できる程度のあのである。

終わりに，たえずご指導とご援助をいただく，本学 野中作太郎教授に愿く感謝の意を表します。

(昭和 53 年 11 月 7 日受付)

\section{文献}

（1）山田・岩本・伊藤：「誘導反発形磁気浮上方式におり磁気 ダンピング」電学諭 B 94、49(昭 49-1)

（2）雨容・大熊: 「超蹗導㮇溥反発浮上系の磁気ダンピングに開 ذ万端部効果」笔学睮 $B$ 97,708 (昭 52-11)

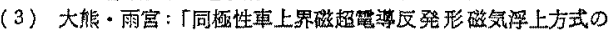
特性」電学猃 B 98, 347 (四 53-4)

(4) B.T. Ooj: "Electromechanical stiffness and damping coefficients in the repulsive magnetic levitation system" IEEE Trans. Power Appartus. Syst. PAS- 95, 936 (1976)

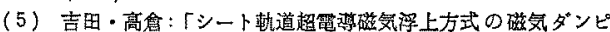

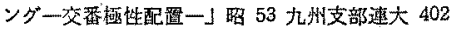

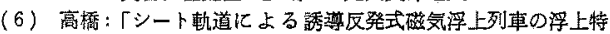

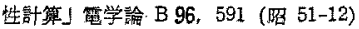

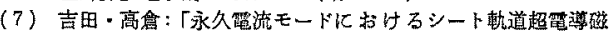
気泽上系の浮上特性」九大工学策報 51，809 (昭 53-12)

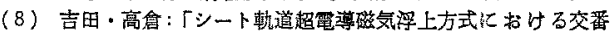

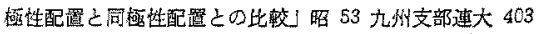

\section{付 録}

\section{第 $\boldsymbol{i}$ 番目車上コイルの鎖交磁束 $\lambda$}

車上コイル位置 $z=h$ での $z$ 成分磁束密度を $B_{z 1}$ II とすれば，車上コイル群の最後加ら第i番目コイルの 鎖交磁束 $\lambda_{i}$ は,

$$
\begin{aligned}
\lambda_{i} & =N_{s c} \int_{-w_{s c} / 2}^{w_{s c} / 2} \int_{(i-1) l_{p}}^{(i-1) l_{p}+l_{s e}} \operatorname{Re}\left(B_{z 1} \mathbb{I}\right) d x^{\prime} d y \\
& \left.=\sum_{j=1}^{P_{s c}} L_{i j}\left(h, v_{z}\right) I_{s c j}\left(h, v_{z}\right) \ldots \ldots \ldots \text { (付 } 1\right)
\end{aligned}
$$

但し，

$$
\begin{aligned}
& L_{i j}\left(h, v_{z}\right)=(\mp 1)^{j-1} \sum_{m} \sum_{n} \frac{32}{\pi^{4}} \mu_{0} N_{s c}{ }^{2}\left(L_{1} w_{p}\right) \\
& \quad \times\left(\frac{k_{u, m n}}{m n}\right)^{2} k_{m n}\left\{f_{R}\left(h, v_{z}\right) \cos (i-j) k_{x m} l_{p}\right. \\
& \left.\left.\quad+f_{I}\left(h, v_{z}\right) \sin (i-j) k_{x m} l_{p}\right\} \ldots \text { (付 } 2\right) \\
& f\left(h, v_{z}\right)=f_{R}\left(h, v_{z}\right)+j f_{I}\left(h, v_{z}\right) \\
& =1-\frac{v_{2}+j \frac{1}{2} \mu_{0} \sigma d v_{z} v_{m n}}{v_{2}-j\left(1+\frac{1}{2} \mu_{0} \sigma d v_{z}\right) v_{m n}} \\
& \left.\quad \times \varepsilon^{-2 k_{m n} h} \ldots \ldots \ldots \ldots \ldots \ldots \ldots \ldots \ldots \text { (付 } 3\right)
\end{aligned}
$$

